\title{
Further studies on the effects of the presence or absence of protozoa in the rumen on live-weight gain and wool growth of sheep
}

\author{
BY S. H. BIRD AND R. A. LENG \\ Department of Biochemistry and Nutrition, University of New England, Armidale, NSW \\ 2351, Australia
}

(Received 23 January 1984 - Accepted 2 July 1984)

1. Lambs were given a diet of oaten chaff-sucrose-fishmeal (48:48:4,w/w) and either 60 (diet A) or 120 (diet B) $\mathrm{g}$ urea $/ \mathrm{kg}$ sucrose in the diet. All animals were defaunated and half were refaunated. Each group of lambs (faunated and defaunated) was then divided into two groups and given diet A or diet B. Feed intake, wool growth and live-weight change were monitored over a $182 \mathrm{~d}$ period.

2. The level of urea supplementation had no effect on wool growth or live-weight gain.

3. Defaunated lambs gained live weight at a higher rate $(9 \%, P<0.06)$ and grew $37 \%$ more wool $(P<0.01)$ than the lambs with large populations of protozoa in their rumens.

In previous studies from these laboratories, production was compared in faunated and defaunated young steers and lambs on low-protein, high-energy diets. Increases in live-weight gain of young steers, and large increases in wool growth and live-weight gain of lambs, were associated with the absence of protozoa in the rumen (Bird \& Leng, 1978; Bird et al. 1979). The increased rates of wool growth suggest that more sulphur amino acids were absorbed from the gut of the defaunated lambs as compared with the faunated control animals (see Reis \& Tunks, 1969).

Bird et al. (1979) found that the concentrations of ammonia in rumen fluid were much lower in defaunated than in faunated lambs on the same diet, a result consistent with previously reported experiments with sheep (Christiansen et al. 1965; Males \& Purser, 1970; Eadie \& Gill, 1971; Lindsay \& Hogan, 1972). The concentration of ammonia in the rumen fluid of defaunated lambs was at times less than that at which ammonia apparently limits the efficiency of microbial growth (Satter \& Slyter, 1974; Pisulewski et al. 1981). In addition, the original feeding trials of Bird et al. (1979) were over only a 6-week period which could be misleading, particularly if rumen ammonia concentrations were at times limiting production. For these reasons a trial similar to that of Bird et al. (1979) was established but in this feeding trial two levels of urea in the diet of the lambs were examined and the experiment was continued for 26 weeks. Also, in contrast to the earlier work, all animals in this study were initially defaunated and then half refaunated at the commencement period, thus eliminating bias due to defaunation treatment.

There was no apparent effect of the level of fermentable nitrogen in the diet; the defaunated lambs, however, had higher live-weight gains and grew substantially more wool than the faunated lambs.

\section{MATERIALS AND METHODS \\ Experimental animals}

Mixed sex Merino $\times$ Border Leicester lambs, approximately 4 months of age and weighing about $16 \mathrm{~kg}$ live weight, were obtained from a flock of lambs at pasture. Animals were held in individual pens with free access to clean water. All animals were allowed 3 weeks to adjust 
to a basal diet of oaten chaff and sugar during which time they were drenched to remove internal parasites with Ranizole (Merck, Sharpe \& Dohme, Australia Pty Ltd), Ranide (Merck, Sharpe \& Dohme) and Nilverm (ICI Australia Ltd) given at 4-d intervals.

\section{Diet}

All lambs were given a basal diet of oaten chaff and sugar $(1: 1, \mathrm{w} / \mathrm{w}) \mathrm{ad}$ lib. For every $1 \mathrm{~kg}$ sugar in the diet, $80 \mathrm{~g}$ fishmeal were added together with $10 \mathrm{~g}$ sodium sulphate, $10 \mathrm{~g}$ calcium pyrophosphate, $10 \mathrm{~g}$ sodium chloride and $10 \mathrm{~g}$ of a mineral-vitamin mix (Minavit, Cooper (Australia) Pty Ltd). The diet was supplemented with either 60 or $120 \mathrm{~g}$ urea $/ \mathrm{kg}$ sugar providing two diets (diets A and B). Animals were given feed at 09.00 hours each day.

\section{Experimental procedures}

Fifty lambs were defaunated with an anionic detergent alkanate 3SL3 (active ingredient sodium lauryl diethoxy sulphate; ICI Australia Ltd) delivered directly into the rumen through a polythene tube inserted down the oesophaghus. Each animal was given three separate doses of alkanate $(20 \mathrm{ml}$ in $100 \mathrm{ml}$ water). These were given on each of three consecutive days. Feed was not provided during this period. The treatment resulted in the death of two animals. One animal required a second treatment after it was found to contain a small population of protozoa $21 \mathrm{~d}$ after the initial dose. Forty defaunated lambs with the highest feed intakes were selected and divided into two groups of twenty lambs; the groups were chosen to be similar in live weight and sex. One group was then re-inoculated with $50 \mathrm{ml}$ rumen fluid on three consecutive days. The inoculum was collected from sheep with high populations of rumen protozoa and on a similar diet. The faunated and defaunated groups were each divided on the basis of weight into two equal groups of ten lambs (seven females and three males) one of which was given diet A and other diet B.

Rumen fluid samples were collected every 2-3 weeks from all lambs throughout the 26-week period and examined for protozoa. Protozoa were enumerated in the rumen fluid from the faunated sheep using the procedures previously described (see Bird et al. 1979).

Wool production was measured using the dye-band method of Chapman \& Wheeler (1963), and daily feed intakes and weekly body-weights were recorded over the 26-week period.

Differences between treatment effects were analysed statistically by analysis of variance (Snedecor \& Cochran, 1968).

\section{RESULTS \\ Protozoal population density}

The protozoal populations in the rumen of the refaunated lambs increased rapidly following inoculation. The level of urea in the diet did not influence the number of protozoa in the rumen and the mean values for lambs at $28 \mathrm{~d}$ in both dietary groups are given in Table 1. Overall there were twenty observations showing an average density of $1.2 \times 10^{6}$ (SE $\left.0 \cdot 12 \times 10^{6}\right) / \mathrm{ml}$. The protozoal population consisted of small Entodinium spp. $(96 \%)$, Epidinium spp. (3\%) and other large spirotrichs $(1 \%)$. The rumen fluid inoculum used to refaunate the lambs also contained Isotricha spp. but they were not observed in the experimental lambs during the 26-week period.

\section{Feed intake, live-weight gain and wool growth rate}

The results obtained for feed intake, live-weight gain, feed conversion efficiency and wool production of each group of lambs are summarized in Table 1. Defaunation had no effect on feed intake or feed conversion efficiency; however, weight gain $(P<0.06)$ and wool 
Table 1. Growth rate $(\mathrm{g} / \mathrm{d})$, feed conversion efficiency ( $g$ dry matter intake $(D M I) / g$ live-weight gain) and wool growth rate $(\mathrm{g} / \mathrm{d})$ of faunated and defaunated lambs fed ad lib. a basal diet of oaten chaff and sugar (containing $80 \mathrm{~g}$ fishmeal $\mathrm{kg}$ sugar) and supplemented with two levels of urea (60 or $120 \mathrm{~g} / \mathrm{kg}$ sugar); diets $A$ and $B$ respectively

(Mean values for ten animals per group)

\begin{tabular}{|c|c|c|c|c|c|c|c|}
\hline Diet & Group & $\begin{array}{l}\text { Initial } \\
\text { live } \\
\text { wt } \\
(\mathrm{kg})\end{array}$ & $\begin{array}{c}\text { Mean } \\
\text { concentration } \\
\text { of protozoa } \\
\text { in rumen fluid } \\
(\text { no. } / \mathrm{ml})\end{array}$ & $\begin{array}{l}\text { DMI } \\
(\mathrm{g} / \mathrm{d})\end{array}$ & $\begin{array}{l}\text { Live- } \\
\text { wt } \\
\text { gain } \\
\text { (g/d) }\end{array}$ & $\begin{array}{c}\text { Feed } \\
\text { conversion } \\
\text { efficiency } \\
\text { (g DMI } / \mathrm{g} \text { live-wt } \\
\text { gain) }\end{array}$ & $\begin{array}{c}\text { Wool } \\
\text { growth } \\
\text { (clean) } \\
(\mathrm{g} / \mathrm{d})\end{array}$ \\
\hline A & Faunated & 16 & $1.2 \times 10^{6}$ & 865 & 122 & $7 \cdot 3$ & $8 \cdot 0^{\mathrm{a}}$ \\
\hline A & Defaunated & 16 & & 890 & 135 & $6 \cdot 7$ & $10 \cdot 8^{b}$ \\
\hline B & Faunated & 16 & $1.3 \times 10^{6}$ & 870 & 122 & $7 \cdot 2$ & $7 \cdot 9^{\mathrm{a}}$ \\
\hline B & Defaunated & 16 & & 930 & 132 & $7 \cdot 0$ & $11 \cdot 0^{\mathrm{b}}$ \\
\hline SEM & $(36 \mathrm{df})$ & & & $30 \cdot 4$ & 6.4 & 0.19 & 0.41 \\
\hline
\end{tabular}

a,b Values with different superscript letters were significantly different $(P<0 \cdot 01)$.
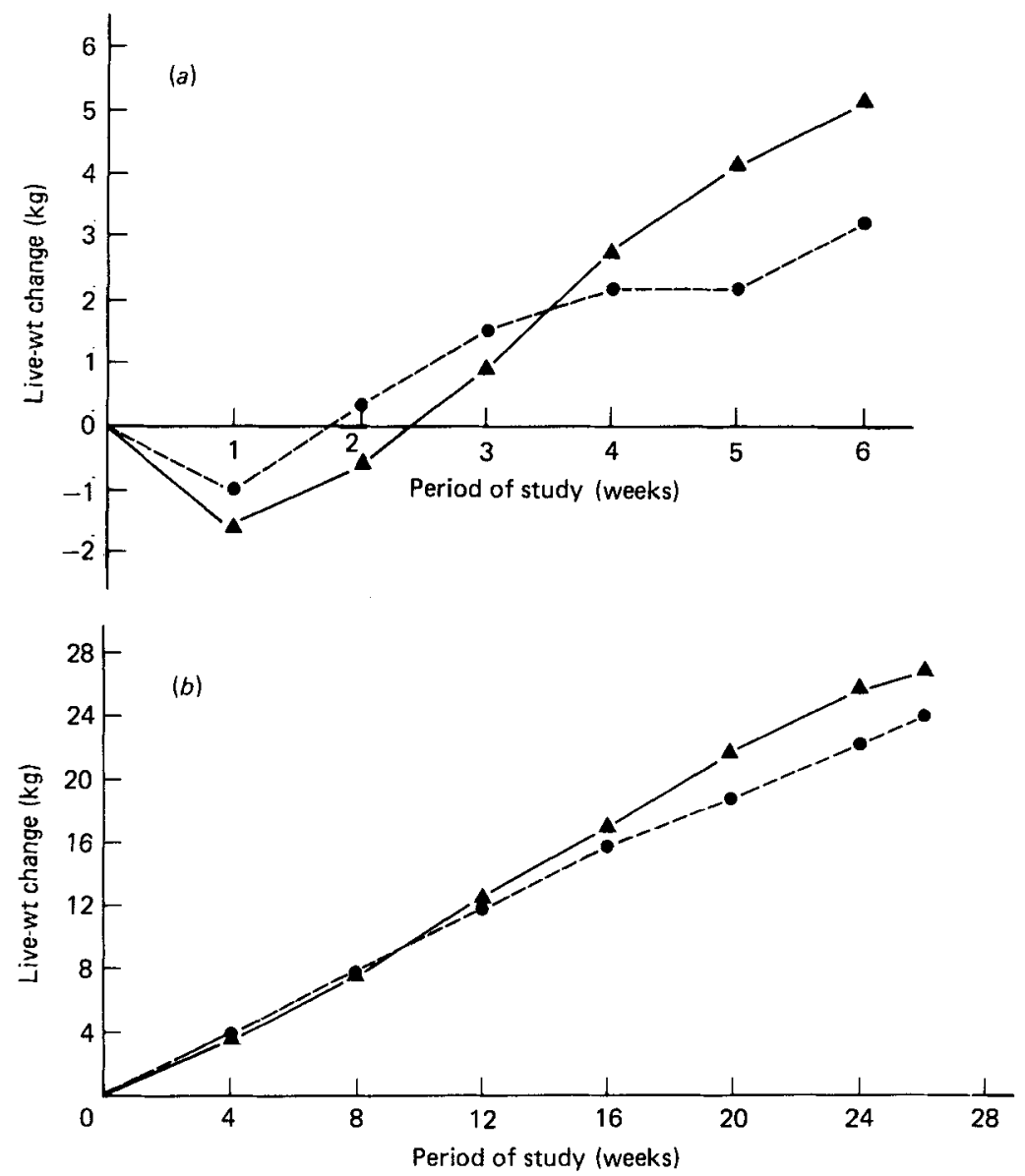

Fig. 1. Live-weight change of faunated $(\boldsymbol{O})$ and defaunated $(\mathbf{A})$ lambs given a basal diet ad lib. of oaten chaff and sugar $(1: 1, \mathrm{w} / \mathrm{w})$ supplemented with fishmeal $(80 \mathrm{~g} / \mathrm{kg}$ sugar) and (a) $60 \mathrm{~g}$ urea $/ \mathrm{kg}$ sugar (diet A), mean values of six animals per group, after Bird et al. (1979) or (b) 60 and $120 \mathrm{~g} \mathrm{urea} / \mathrm{kg}$ sugar (diets $A$ and $B$ respectively), mean values of twenty animals per group, present study. 
production $(P<0 \cdot 01)$ were higher in defaunated lambs. There were no apparent differences between the two dietary groups within either the faunated or defaunated groups of lambs.

The live-weight changes of faunated and defaunated lambs are shown in Fig. $1 b$ and compared with the results from Bird et al. 1979 (Fig. 1 a) where only the defaunated group were treated with the chemical to remove protozoa from the rumen.

\section{DISCUSSION}

In the earlier experiments of Bird et al. (1979) only half the lambs were defaunated which resulted in a weight loss which was greater in the treated than in the untreated groups of lambs during the inital weeks of the experiment (Fig. 1a). Demeyer et al. (1982) reported a similar finding in an experiment to examine the effects of defaunation in which only half the lambs were treated for the removal of protozoa. These workers observed increased growth rates of lambs following defaunation; however, the final live weights of the faunated and defaunated groups of lambs were almost identical. In our own laboratories (Burggraaf, 1980) similar results have been obtained in which the benefits of the defaunated state, in terms of live-weight gain, were apparently negated, for some time, by the detrimental effects of the treatment used to remove the protozoa.

In the present study all lambs were initally defaunated and allowed sufficient time to regain full appetite prior to allocation to treatment groups. The voluntary feed intake of the defaunated and refaunated groups were similar during the first week of the experiment and so no differential loss of live weight occurred during this period (Fig. $1 b$ ). Therefore the design of the experiment eliminates any bias which may be associated with the direct action of the chemical defaunating agent on the animal.

Defaunation was associated with a moderate increase in live-weight gain $(9 \%)$ which was significantly different at $P<0.06$, and a large and highly significant $(P<0.01)$ increase in wool growh $(37 \%)$. The magnitude of the wool growth response was comparable with the earlier short-term study of Bird et al. (1979). A comparison of the cumulative weight gains of the lambs in both studies (Fig. $1 a, b$ ) showed that the response of the defaunated lambs in the present study was much slower than the response associated with defaunation in the earlier work. It is suggested that some of the increased weight gain in lambs recorded in the earlier study was due to an increase in rumen fill in the defaunated lambs as reported by Burggraaf (1980). At the completion of the present study two wethers of similar weight were selected from the faunated and defaunated groups of lambs and slaughtered (S. H. Bird, unpublished observations). The weight and volume of rumen contents and dressing percentage were similar for both faunated and defaunated animals, suggesting that, in this experiment, higher growth rates of the defaunated lambs were not due to rumen fill. However, further work is needed with more animals before this conclusion can be confirmed.

The large increase in wool growth rate associated with the absence of protozoa in the rumen was the most important result arising from this study. As wool growth rate is highly sensitive to the amounts of S-amino acids absorbed from the intestines (Reis \& Schinckel, 1961 ) it is reasonable to assume that the removal of protozoa from the rumen increased the amount of S-amino acids (and thus total protein) available for absorption in the animal. Further, it is suggested that a major proportion of this increased supply of protein was of microbial origin as has been shown in several studies (although with relatively few cannulated animals) in which protein outflow from the rumen was measured in faunated and defaunated sheep (Lindsay \& Hogan, 1972; Rowe et al. 1981; Bird \& Leng, 1983; Veira $\&$ Ivan, 1983). The benefits from the defaunated state in sheep are therefore largely due to increases in the ratio, protein:energy in the products of fermentation available for 
absorption (see Leng, 1982). The results also show that the benefits of defaunation are not short-term.

The financial support of the Australian Meat Research Committee and the Australian Wool Corporation is gratefully acknowledged. Mr R. Woodgate gave valuable technical assistance.

\section{REFERENCES}

Bird, S. H., Hill, M. K. \& Leng, R. A. (1979). British Journal of Nutrition 42, 81-87.

Bird, S. H. \& Leng, R. A. (1978), British Journal of Nutrition 40, 163-167.

Bird, S. H. \& Leng, R. A. (1983). In Recent Advances in Animal Nutrition in Australia 1983, pp. 111-118

[D. J. Farrell and Pran Vohra, editors]. Armidale: University of New England Publishing Unit.

Burggraaf, W. (1980). Masters Thesis. University of New England, Armidale, Australia.

Chapman, R. E. \& Wheeler, J. L. (1963). Australian Journal of Science 26, 53-54.

Christiansen, W. C., Kawashima, R. \& Burroghs, W. (1965). Journal of Animal Science 24, 730-734.

Demeyer, D. I., Van Nevel, C. J. \& Van De Voorde, G. (1982). Archiv für Tierernährung, Berlin 32, 595-604.

Eadie, M. J. \& Gill, J. C. (1971). British Journal of Nutrition 26, 155-167.

Leng, R. A. (1982). British Journal of Nutrition 48, 399-415.

Leng, R. A., Davis, J. \& Hill, M. K. (1984). Proceedings of the Australian Society of Animal Production 15, 431.

Lindsay, J. R. \& Hogan, J. A. (1972). Australian Journal of Agricultural Research 23, 321-330.

McDonald, I. W. (1952). Biochemical Journal 51, 86-90.

Males, J. R. \& Purser, D. B. (1970). Applied Microbiology 19, 485-490.

Pisulewski, P. M., Okorie, A. U., Buttery, P. J., Haresign, W. R. \& Lewis, D. (1981). Journal of the Science of Food and Agriculture 32, 759-766.

Reis, P. J. \& Schinckel, P. G. (1961). Australian Journal of Agricultural Research 12, 335-352.

Reis, P. J. \& Tunks, D. A. (1969). Australian Journal of Agricultural Research 20, 775-781.

Rowe, J. B., Davies, A. \& Broome, A. W. J. (1981). Proceedings of the Nutrition Society 40, 49A.

Satter, L. D. \& Slyter, L. L. (1974). British Journal of Nutrition 32, 199-208.

Snedecor G. W. \& Cochran W. G. (1968). Statistical Methods. Ames, Iowa: Iowa State University Press.

Veira, D. M. \& Ivan, M. (1983). Journal of Dairy Science 66, 1015-1022. 